\title{
Evidence that the preovulatory rise in intrafollicular progesterone may not be required for ovulation in cattle
}

\author{
Qinglei $\mathbf{L i}^{1,2}$, Fermin Jimenez-Krassel ${ }^{1,2,4}$, Anilkumar Bettegowda ${ }^{1,2}$, James J Ireland ${ }^{2,3,4}$ and \\ George W Smith ${ }^{1,2,3}$ \\ ${ }^{1}$ Laboratory of Mammalian Reproductive Biology and Genomics, ${ }^{2}$ Departments of Animal Science ${ }^{3}$ Physiology ${ }^{4}$ Molecular Reproductive Endocrinology \\ Laboratory, Michigan State University, East Lansing, Michigan 48824, USA \\ (Requests for offprints should be addressed to G W Smith; Email: smithge7@msu.edu)
}

\begin{abstract}
Despite ample evidence pointing to an obligatory involvement of progesterone in ovulation, the mechanisms responsible for the ovulation promoting effects of intrafollicular progesterone are unclear. The objectives of this study were to determine if ovulation, luteinization and the gonadotropin surge-induced regulation of select extracellular matrix-degrading enzymes and their inhibitors, and mRNAs for prostaglandin (PG) biosynthesis and metabolizing enzymes are blocked following suppression of the intrafollicular increase in progesterone. Bovine preovulatory follicles were injected with the $3 \beta$-hydroxysteroid dehydrogenase inhibitor trilostane or diluent and collected at 0,12 , and $24 \mathrm{~h}$ after $\mathrm{GnRH}$ induction of the preovulatory LH surge. Intrafollicular trilostane administration blocked the preovulatory increase in follicular fluid progesterone resulting in concentrations similar to those observed at time 0 post$\mathrm{GnRH}$ injection. The preovulatory increase in follicular fluid $\mathrm{PGE}_{2}$ and $\mathrm{PGF}_{2 \alpha}$ was reduced in trilostane-treated
\end{abstract}

follicles and accompanied by upregulation of prostaglandin dehydrogenase mRNA in the granulosal and thecal cells. However, follicle rupture was not blocked by inhibition of the preovulatory rise in intrafollicular progesterone, and normal serum progesterone concentrations were observed during subsequent luteal development. Effects of trilostane administration on preovulatory changes in mRNA abundance and protein/activity in preovulatory follicles for most regulators of extracellular matrix remodeling examined were distinct from changes previously observed following the inhibition of intrafollicular prostaglandin synthesis. Results suggest that the preovulatory increase in intrafollicular progesterone may not be obligatory for bovine follicle rupture, luteinization, or regulation of prominent matrixdegrading proteinases and their inhibitors associated with ovulation.

Journal of Endocrinology (2007) 192, 473-483

\section{Introduction}

Ovulation, triggered by the preovulatory luteinizing hormone (LH) surge, is a prerequisite for fertilization and embryonic development. Preovulatory degradation of the extracellular matrix at the follicle apex is a hallmark of the ovulatory process (Fata et al. 2000, Ny et al. 2002). Available evidence indicates that local regulation of genes implicated in the tissue remodeling process, including members of two major families of proteolytic enzymes, the matrix metalloproteinase (MMP) and the plasminogen activator (PA)/ plasmin system (Iwamasa et al. 1992, Tanaka et al. 1992, Chaffin \& Stouffer 1999), and their cognate inhibitors, controls the targeted degradation of the follicular extracellular matrix required for ovulation.

We have previously demonstrated gonadotropin surgeinduced regulation of expression of several key MMP and PA system components in bovine preovulatory follicles, including MMP-13 (Bakke et al. 2004), MMP-14 (Bakke et al.
2002), MMP-28 (Li et al. 2006), tissue inhibitor of metalloproteinases (TIMPs) 1-4 (Smith et al. 1996, Bakke et al. 2002, Li et al. 2004), tissue-type plasminogen activator (tPA), urokinase-type plasminogen activator (uPA), the uPA receptor (uPAR; Dow et al. 2002a), and plasminogen activator inhibitors 1 and 2 (PAI-1 and PAI-2; Dow et al. 2002b). A requirement of intrafollicular prostanoids for bovine follicle rupture (De Silva \& Reeves 1985, Peters et al. 2004) and gonadotropin surge-induced regulation of specific MMP and PA system components (Li et al. 2006) has been demonstrated. However, increased intrafollicular progesterone is characteristic of the luteinization process accompanying bovine ovulation (Dieleman et al. 1983, Sirois 1994). It is not known whether the preovulatory increase in the intrafollicular progesterone per se mediates the gonadotropin surge-induced changes in the expression of above regulators of the follicular extracellular matrix in bovine follicles and if such effects are potentially mediated by progesterone-induced regulation of prostanoids, such as 
prostaglandin $(\mathrm{PG}) \mathrm{E}_{2}$. Thus, in view of the essential role of progesterone in promoting follicle rupture in other species (Espey et al. 1990, Hibbert et al. 1996), we hypothesized that the preovulatory increase in the intrafollicular progesterone of the dominant ovulatory follicle is required for ovulation and gonadotropin surge-induced regulation of $\mathrm{PGE}_{2}$, $\mathrm{PGF}_{2 \alpha}$, and the above mentioned regulators of extracellular matrix remodeling in bovine preovulatory follicles. Thus, in the present study, intrafollicular injection of a $3 \beta$-hydroxysteroid dehydrogenase ( $3 \beta-\mathrm{HSD})$ inhibitor (trilostane) to block the preovulatory rise in intrafollicular progesterone was used as a tool to investigate the requirement of increased intrafollicular progesterone for bovine ovulation and gonadotropin surge-induced intrafollicular regulation of mediators of the tissue remodeling process and other molecular, hormonal, and (or) biochemical indices of ovulation and luteinization.

\section{Materials and Methods}

\section{Animal model}

Mature Holstein cows (Bos taurus; $\geq 2$ years old, 449$680 \mathrm{~kg}$ ) were fed a balanced corn silage diet and housed at the Michigan State University Beef Cattle Research Center during the course of the experiments. Experimental procedures were approved by the All University Committee on Animal Use and Care at Michigan State University. The model utilized in this study has been described previously (Bakke et al. 2002, 2004). Briefly, follicular development and timing of the preovulatory gonadotropin surge were synchronized using the Ovsynch procedure established by Pursley et al. $(1995,1997)$ with slight modifications. In brief, the first gonadotrophin-releasing hormone $(\mathrm{GnRH})$ injection was given to initiate a new wave of follicular growth resulting in a new dominant follicle. $\mathrm{PGF}_{2 \alpha}$ was then injected to regress the corpus luteum 6.5 days later. A second dose of $\mathrm{GnRH}$ was given $36 \mathrm{~h}$ later to trigger the gonadotropin surge and ovulation of the dominant follicle. Synchronized ovulation of the dominant follicle occurs an average of $29 \mathrm{~h}$ after the second GnRH injection (Pursley et al. 1995). Trilostane (4,5-epoxy-17-hydroxy-3-oxoandrostane-2-carbonitrile; Sanofi-Synthelabo Research, Malvern, PA, USA), an inhibitor of $3 \beta-\mathrm{HSD}(10 \mu \mathrm{M}$ final concentration in follicular fluid), or diluent (PBS; control) was injected into preovulatory follicles immediately after the second GnRH injection using previously described ultrasound-mediated intrafollicular injection procedures (Peters et al. 2004). Dose of trilostane administered was selected based on the results of a preliminary dose response experiment, comparing effects of different trilostane concentrations $(1,2,5$, and $10 \mu \mathrm{M})$ on follicular fluid progesterone levels $24 \mathrm{~h}$ after GnRH injection (data not shown).
Effects of intrafollicular trilostane administration on follicular fluid hormone concentrations and granulosal and thecal cell $m R N A$ and (or) protein for regulators of extracellular matrix remodeling and prostaglandin biosynthesis/metabolism

Experiment 1 For investigation of the effects of intrafollicular injection of trilostane on changes in mRNA and (or) protein/activity for matrix-degrading proteinases and their inhibitors, mRNA for cyclooxygenases 1 and 2 (COX-1 and COX-2; enzymes responsible for the conversion of arachidonic acid to prostaglandins), the NAD+dependent 15-hydroxy prostaglandin dehydrogenase (PGDH; the key enzyme that metabolizes $\mathrm{PGE}_{2}$ and $\mathrm{PGF}_{2 \alpha}$ to biologically inactive 15-keto derivatives) and oxytocin, and follicular fluid progesterone, estradiol, $\mathrm{PGE}_{2}$ and $\mathrm{PGF}_{2 \alpha}$ concentrations, ovaries containing preovulatory follicles were collected at 0 ( $n=5$ animals), $12(n=3$ and 5 for controls and trilostane treated respectively), and $24 \mathrm{~h}$ $(n=3$ and 6 for controls and trilostane treated respectively) after the second GnRH injection. Follicular fluid was aspirated from each follicle and centrifuged to remove potential blood cell contamination. Indomethacin was then added to follicular fluid (to prevent ex vivo generation of eicosanoids) to achieve a final concentration of $3.6 \mu \mathrm{g} / \mathrm{ml}(\mathrm{Li}$ et al. 2006) before it was frozen in liquid nitrogen and stored at $-80^{\circ} \mathrm{C}$. Dissection of preovulatory follicles was described previously (Bakke et al. 2002, Li et al. 2004). The dissected follicles were sagitally cut into several portions for granulosal cells (GC) and thecal tissue (TC) isolation and for protein extraction. GC were scraped from the theca interna of preovulatory follicles and collected by centrifugation, while TC was isolated from a portion of the same follicles. TRIzol (Life Technologies, Inc., Gaithersburg, MD, USA) was added to the GC immediately after collection. Follicle apex and base containing GC and TC were separated from another portion of the same follicles for protein extraction. All the above samples were snap frozen in liquid nitrogen and stored at $-80^{\circ} \mathrm{C}$ until use.

Effects of intrafollicular trilostane administration on follicle rupture and subsequent luteal function

Experiment 2 To examine the effect of trilostane on bovine follicle rupture and subsequent luteal function, cows were injected (in two replicates) with trilostane $(n=13$ total) or diluent ( $n=17$ total) immediately after the second $\mathrm{GnRH}$ injection and follicle rupture was monitored (beginning immediately after intrafollicular injection) by ultrasonography every $12 \mathrm{~h}$ for 2 days. Blood samples were collected at 2 to 3-day intervals (days $0,2,4,7,9$, and 11) after intrafollicular trilostane injection and sera were separated from animals $(n=7$ and 9 for trilostane treated and control respectively) in the second replicate of the above experiment. Sera were frozen at $-20^{\circ} \mathrm{C}$ until progesterone assay. 
Steroid hormone radioimmunoassays

Concentrations of progesterone in follicular fluid and serum were measured by RIA using a commercially available kit (Diagnostic Products Corp., Los Angeles, CA, USA) as described previously (Peters et al. 2004). Intra- and interassay coefficients of variation (CV) were 5 and $9 \%$ respectively. Concentrations of estradiol-17 $\beta$ in follicular fluid samples were measured by RIA (Diagnostic Products Corporation) in a single assay (Jimenez Krassel \& Ireland 2002). Intraassay CV was 5•4\%.

Follicular fluid $\mathrm{PGE}_{2}$ and $\mathrm{PGF}_{2 \alpha}$ assays

Concentrations of follicular fluid $\mathrm{PGE}_{2}$ were analyzed using a $\mathrm{PGE}_{2}$ enzyme immunoassay (EIA; Cayman Chemical, Ann Arbor, MI, USA) as described previously (Peters et al. 2004). Concentrations of follicular fluid $\mathrm{PGF}_{2 \alpha}$ were analyzed using a $\mathrm{PGF}_{2 \alpha}$ EIA (Cayman Chemical). Follicular fluid was diluted in EIA buffer before analysis in separate single assays for $\mathrm{PGE}_{2}$ and $\mathrm{PGF}_{2 \alpha}$. Intraassay $\mathrm{CV}$ were $3 \cdot 1$ and $5 \cdot 5 \%$ for $\mathrm{PGE}_{2}$ and $\mathrm{PGF}_{2 \alpha}$ respectively.
$R N A$ isolation and quantitative real-time RT-PCR

Total RNA was extracted from GC and TC of bovine preovulatory follicles using TRIzol reagent according to the manufacturer's instructions. One microgram of total RNA from each sample was incubated for $15 \mathrm{~min}$ at $25^{\circ} \mathrm{C}$ with $1 \mathrm{U}$ DNase I (Invitrogen) to eliminate possible genomic DNA contamination before reverse transcription which was detailed elsewhere (Li et al. 2004). Real-time PCR was applied to quantify mRNA levels for genes of interest in GC/TC of trilostaneversus diluent-treated control follicles. Real-time PCR primers were designed using Primer Express program (Primer Express, Applied Biosystems, Foster City, CA, USA) and the primer information is indicated in Table 1 . The PCRs (25 $\mu$ l volume) contained 12.5 $\mu \mathrm{l}$ SYBR Green PCR Master Mix (Applied Biosystems), 20 ng cDNA and primers (Table 1) for each gene and were run using an ABI Prism 7000 Sequence Detection System (Applied Biosystems) with a program consisting of 40 cycles of $95^{\circ} \mathrm{C}$ for $15 \mathrm{~s}$ and $60^{\circ} \mathrm{C}$ for $1 \mathrm{~min}$ (Li et al. 2004). The reactions were set up in duplicate in a 96-well plate (Applied Biosystems) and the mean cycles to threshold (CT) were

Table 1 Primers utilized for quantification of mRNA abundance by real-time PCR

Genbank accession no. Primer sequence

$\begin{array}{ll}\begin{array}{ll}\text { Gene name } \\ \text { MMP-13 }\end{array} & \text { AF072685 } \\ \text { MMP-14 } & \text { AF290429 } \\ \text { MMP-28 } & \text { XM_583321 } \\ \text { TIMP-1 } & \text { M60073 } \\ \text { TIMP-2 } & \text { AF144764 } \\ \text { TIMP-3 } & \text { U77588 } \\ \text { TIMP-4 } & \text { AF037273 } \\ \text { tPA } & \text { X85800 } \\ \text { uPA } & \text { X85801 } \\ \text { uPAR } & \text { S70635 } \\ \text { PAI-1 } & \text { X16383 } \\ \text { PAI-2 } & \text { AF416234 } \\ \text { Oxytocin } & \text { X00950 } \\ \text { COX-1 } & \text { AF004943 } \\ \text { COX-2 } & \text { AF004944 } \\ \text { PGDH } & \text { BE237549 } \\ \text { RPL-19 } & \text { XM_587778 } \\ \text { TI } & \end{array}$

\begin{tabular}{|c|c|}
\hline \multicolumn{2}{|l|}{$\begin{array}{l}\text { Forward: GCAGAGAGCTACCTGAAATCATACTACT; } \\
\text { Reverse: AATCACAGAGCTTGCTGCAGTTT }\end{array}$} \\
\hline Forward: CCTCAACCCAGGACCACTTC; & $300 / 300$ \\
\hline Reverse: GGCCCGTAGGTGGGATTTT & \\
\hline Forward: CAGGGAAGGCGTCCAGAA; & $300 / 900$ \\
\hline Reverse: CAGTGACGGCATCGAAGGA & \\
\hline Forward: GCACATCACCACCTGCAGTT; & $50 / 50$ \\
\hline Reverse: CCGGCGCTGAGCAGAA & \\
\hline Forward: GGGCTGTGAGTGCAAGATCA; & $300 / 300$ \\
\hline Reverse: CTCGTCCGGAGAGGAGATGTAG & \\
\hline Forward: GATGTACCGAGGATTCACCAAGA; & $300 / 900$ \\
\hline Reverse: TTAAGGCCACAGAGACTTTCAGAA & \\
\hline Forward: GAAAGTCTGAATCACCGCTACCA; & $900 / 300$ \\
\hline Reverse: CAGGGCACCGCATAGCA & \\
\hline Forward: ACGTCAGGTTGTACCCATCCA; & $300 / 300$ \\
\hline Reverse: GTTGTTGGTGACGGTCCTGTT & \\
\hline Forward: GCCGTGACTGTGCCATGA; & $300 / 300$ \\
\hline Reverse: GTGTTGATCCAGGGCAGGAA & \\
\hline Forward: GCCGCGGCCCTATGA; & $300 / 300$ \\
\hline Reverse: GCTTGGGTTCCTCAGTCCTTT & \\
\hline Forward: TGGGCCCGTGGAACAA; & $300 / 300$ \\
\hline Reverse: AGGTCCCGCTGCACGAA & \\
\hline Forward: CCATATGCTGGCGATGTCAGT; & $300 / 300$ \\
\hline Reverse: GCCCGTAGAGGATTCAGCAA & \\
\hline Forward: CCGGCCCCCGATACC; & $50 / 300$ \\
\hline Reverse: TCATTGTCATAATTCCTAGGGATGATT & \\
\hline Forward: CAAGATGGGTCCTGGCTTCA; & $300 / 50$ \\
\hline Reverse: CCATAAATGTGGCCGAGGTCTA & \\
\hline Forward: TTGATTGACAGTCCACCAACTTATAAT; & $300 / 150$ \\
\hline Reverse: GAGCTCTGGTATAATAAGACAGGTTAGAAA & \\
\hline Forward: GAGGCGCTGCTGCTCAAG; & $50 / 300$ \\
\hline Reverse: TGACACCTGCTTCGAGATTCC & \\
\hline Forward: CAGACGATACCGTGAATCTAAGAAGA; & $300 / 300$ \\
\hline
\end{tabular}

Primer ratio $^{\mathrm{a}}(\mathrm{nM} / \mathrm{nM})$

$300 / 300$

$300 / 300$

$300 / 900$

$0 / 300$

00/300

00/300

$300 / 300$

$300 / 300$

$00 / 300$

/300

$00 / 300$

\footnotetext{
${ }^{\text {a }}$ Forward/reverse primer ratio was determined by a primer matrix analysis.
} 
calculated for each sample. The comparative CT method (Livak \& Schmittgen 2001) was used for quantification. Expression of each gene of interest was normalized relative to that of ribosomal protein L-19 (RPL-19) mRNA. $\Delta$ CTwas produced by subtracting the mean CT of RPL-19 from the CT of each target gene. Fold changes in the relative mRNA expression of target genes (except COX-2 in 12- and 24-h samples) relative to $0 \mathrm{~h}$ were determined using the formula $2^{-\Delta \Delta \mathrm{CT}}$, where $\Delta \Delta \mathrm{CT}=\Delta \mathrm{CT}_{12}$ or $24 \mathrm{~h}$ sample $-\Delta \mathrm{CT}_{0}$ h sample. COX-2 mRNA abundance was normalized relative to $12-\mathrm{h}$ timepoints. Control reverse transcription reactions, where reverse transcriptase or template was omitted from reactions, were also analyzed to verify the lack of genomic DNA contamination.

\section{Preparation of protein homogenates}

Homogenates of follicle apex and base were prepared as described previously (Bakke et al. 2002). Protein concentration was determined using Lowry et al. (1951) method and aliquots of protein samples stored at $-20{ }^{\circ} \mathrm{C}$ for western blot and zymography analyses.

\section{Western blot analysis}

Western blot analysis of TIMP-4 protein expression in trilostane-treated versus control follicles was performed according to our previously published protocol ( $\mathrm{Li}$ et al. 2004).

\section{Casein zymography}

Casein zymography was conducted to measure the activity of tPA, uPA, and plasmin in the follicle apex, base, and follicular fluid of the trilostane-treated versus control follicles using our previously established protocols (Dow et al. 2002a).

\section{Statistical analysis}

Differences in the concentrations of follicular fluid progesterone, estradiol, $\mathrm{PGE}_{2}, \mathrm{PGF}_{2 \alpha}$, abundance of protein and (or) mRNA for genes of interest, and activity of PA and plasmin among timepoints or treatment groups were assessed by ANOVA using the General Linear Model procedure of the Statistical Analysis System (SAS; Version 8, SAS Institute, Cary, NC, USA). Differences between individual groups were further analyzed with Tukey's test. When heterogeneity of variance was observed, data were log-transformed before statistical analysis. Analysis of the serum progesterone concentrations in animals following intrafollicular trilostane and control injections was performed using the Proc Mixed function of SAS for repeated measures with treatment, time, and interaction of treatment by time as main effects and cow within treatment as the error term. Data are presented as least square (LS) mean \pm s.E.M. and $P<0.05$ was considered to be statistically significant.

\section{Results}

Effect of intrafollicular trilostane injection on follicular fluid steroid concentrations

Mean follicular fluid progesterone concentrations were $94 \mathrm{ng} / \mathrm{ml}$ in $0-\mathrm{h}$ preovulatory follicle samples collected prior to $\mathrm{GnRH}$ injection, and were significantly increased in control follicles $24 \mathrm{~h}$ after $\mathrm{GnRH}$ administration to induce the preovulatory gonadotropin surge $(P<0 \cdot 05$; Fig. 1A). Follicular fluid progesterone concentrations were lower in trilostane-treated versus control follicles at 12 and $24 \mathrm{~h}$ after GnRH injection (16 and 25\% of those observed in control follicles respectively; $P<0.05$; Fig. 1A) and were not significantly different from those observed in control follicles prior to GnRH injection. Relative to controls, follicular fluid estradiol concentrations were also lower in trilostane-treated follicles collected at 12 and $24 \mathrm{~h}$ after $\mathrm{GnRH}$ injection $(P<0 \cdot 05$; Fig. 1B).
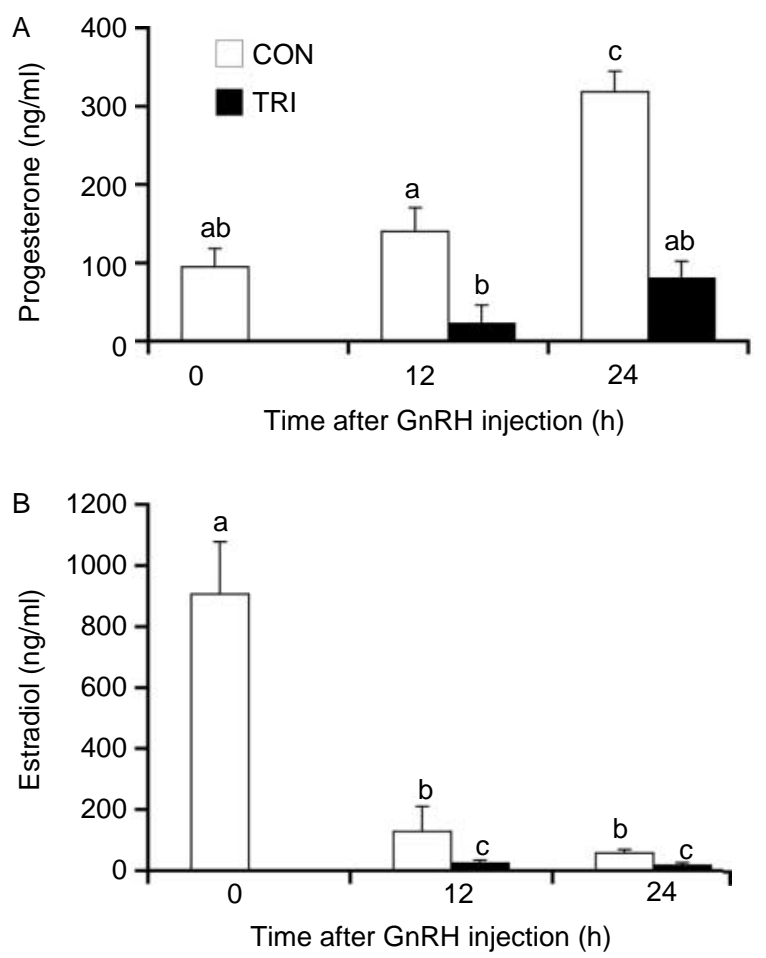

Figure 1 Concentrations of progesterone and estradiol in follicular fluid after GnRH injection and the effect of intrafollicular trilostane (TRI) injection. (A) Progesterone concentrations ( $\mathrm{ng} / \mathrm{ml})$ in follicular fluid of control (CON) animals at $0(n=5), 12(n=3)$, and $24 \mathrm{~h}(n=$ $5)$ after $\mathrm{GnRH}$ injection and TRI-treated animals at $12(n=5)$ and $24 \mathrm{~h}(n=6)$ post-GnRH-injection. (B) Estradiol concentrations $(\mathrm{ng} / \mathrm{ml})$ in follicular fluid of CON animals at $0(n=5), 12(n=3)$, and $24 \mathrm{~h}(n=5)$ after $\mathrm{GnRH}$ injection and TRI-treated animals at $12(n=$ $5)$ and $24 \mathrm{~h}(n=6)$ post-GnRH-injection. Each bar represents the LS mean \pm pooled S.E.M. (A) or mean \pm S.E.M. (B), and bars without a common letter are different at $P<0 \cdot 05$. 
Effect of intrafollicular injection of trilostane on follicle rupture and luteal development in cattle

As determined by ultrasonography, all 17 diluent-treated control animals and 13 trilostane-treated animals ovulated within $48 \mathrm{~h}$ after intrafollicular injection and no difference between control and trilostane-treated animals in timing of ovulation was observed. Oxytocin mRNA increased in response to $\mathrm{GnRH}$ injection $(P<0 \cdot 05$; Fig. $2 \mathrm{~A})$, but no effect of trilostane treatment on oxytocin mRNA abundance was detected (Fig. 2A). Moreover, intrafollicular trilostane administration did not affect amounts or pattern of progesterone production during the timepoints examined (Fig. 2B).
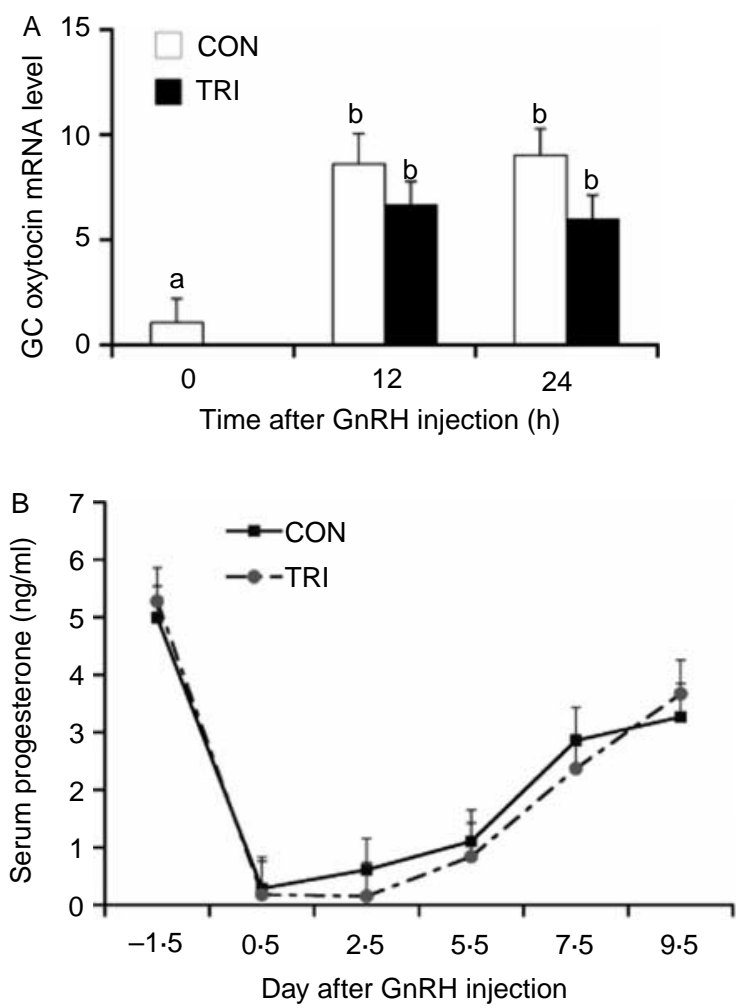

Figure 2 Effect of preovulatory intrafollicular trilostane (TRI) injection on granulosal cell (GC) oxytocin mRNA abundance and serum progesterone concentrations during days 1-9 of the subsequent luteal phase. (A) GC oxytocin mRNA abundance in diluent-treated control (CON) and TRI-treated follicles collected at 0,12 , and $24 \mathrm{~h}$ after $\mathrm{GnRH}$ injection to induce the preovulatory gonadotropin surge. Data are shown as LS means \pm pooled S.E.M., and bars without a common letter are different at $P<0 \cdot 05$. (B) Serum progesterone concentrations in animals subjected to intrafollicular TRI injection versus CON animals. Serum progesterone concentrations were measured on days $-1 \cdot 5,0 \cdot 5,2 \cdot 5$, $5 \cdot 5,7 \cdot 5$, and $9 \cdot 5$ after the second GnRH injection of the Ovsynch procedure, which corresponds to approximately days -3 to 9 of the subsequent luteal phase following intrafollicular TRI injection. A pronounced time effect $(P<0 \cdot 0001)$ was detected, while a significant effect of treatment (TRI injection) and treatment by time interaction were not observed $(P>0 \cdot 05)$.
Effect of intrafollicular trilostane injection on follicular fluid $P G E_{2}$ and $P G F_{2 \alpha}$ concentrations and $m R N A$ abundance for enzymes involved in prostanoid biosynthesis and metabolism

Follicular fluid $\mathrm{PGE}_{2}$ and $\mathrm{PGF}_{2 \alpha}$ concentrations were increased at 24-h post-GnRH injection and intrafollicular trilostane administration reduced the GnRH-induced increase in follicular fluid $\mathrm{PGE}_{2}$ and $\mathrm{PGF}_{2 \alpha}(P<0 \cdot 05$; Fig. 3). Although COX-1 mRNA was detected in GC and $\mathrm{TC}$ at all timepoints examined, its abundance did not change in response to $\mathrm{GnRH}$ injection and trilostane administration (data not shown). COX-2 mRNA was undetectable in GC samples collected prior to GnRH injection (0-h control), but was detectable at 12 and $24 \mathrm{~h}$ and increased at $24 \mathrm{~h}$ relative to the 12-h timepoint $(P<0 \cdot 05$; Fig. $4 \mathrm{~A}$; data normalized relative to 12-h samples). However, treatment of preovulatory follicles with trilostane had no effect on GC COX-2 mRNA abundance (Fig. 4A). Cell-specific effects of GnRH injection on PGDH mRNA abundance in GC and TC were observed (Fig. 4B and C). PGDH mRNA abundance was increased in GC at both 12 and $24 \mathrm{~h}$ following GnRH injection $(P<0 \cdot 05$; Fig. 4B), but suppressed in the TC at the $12-\mathrm{h}$ timepoint
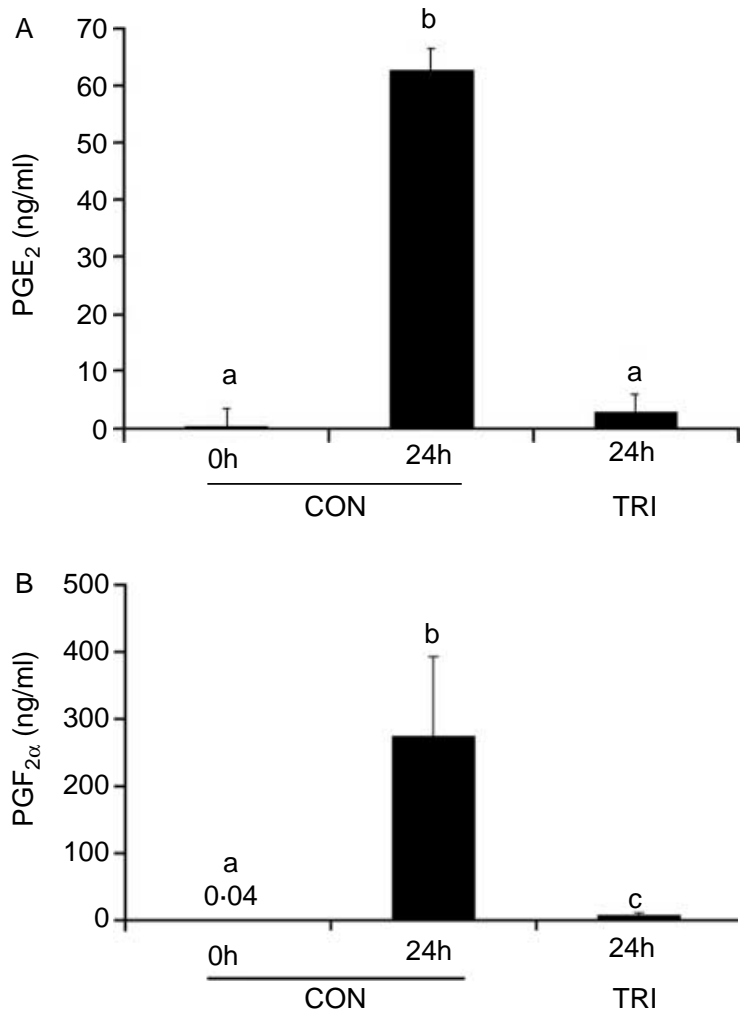

Figure 3 Effect of intrafollicular trilostane (TRI) injection on concentrations of follicular fluid $\mathrm{PGE}_{2}(\mathrm{~A})$ and $\mathrm{PGF}_{2 \alpha}(\mathrm{B})$ in $0-\mathrm{h}$ control (CON; $n=5$ and 4 for $\mathrm{PGE}_{2}$ and $\mathrm{PGF}_{2 \alpha}$ respectively), 24-h CON ( $n=5$ and 4 for $\mathrm{PGE}_{2}$ and $\mathrm{PGF}_{2 \alpha}$ respectively), and 24-h TRI $\left(n=6\right.$ and 5 for $\mathrm{PGE}_{2}$ and $\mathrm{PGF}_{2 \alpha}$ respectively)-treated follicles. Each bar represents the LS mean \pm pooled S.E.M., and bars without a common letter are different at $P<0.05$. 


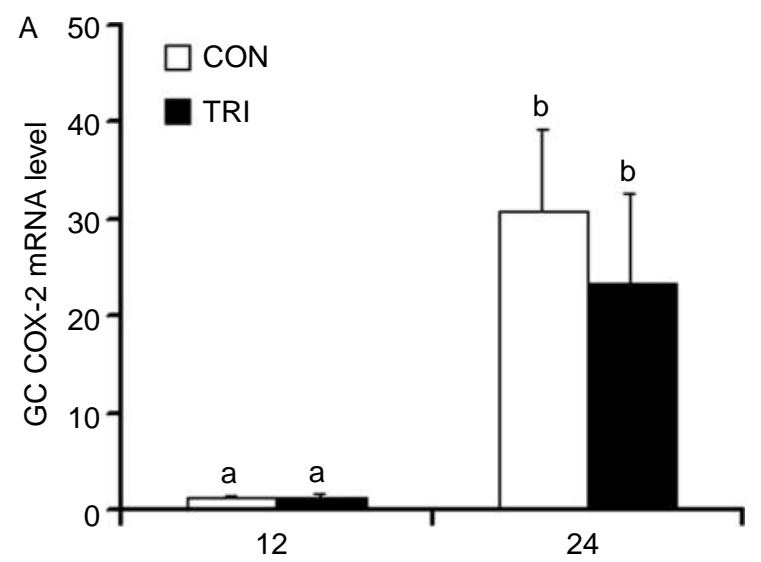

Time after $\mathrm{GnRH}$ injection (h)
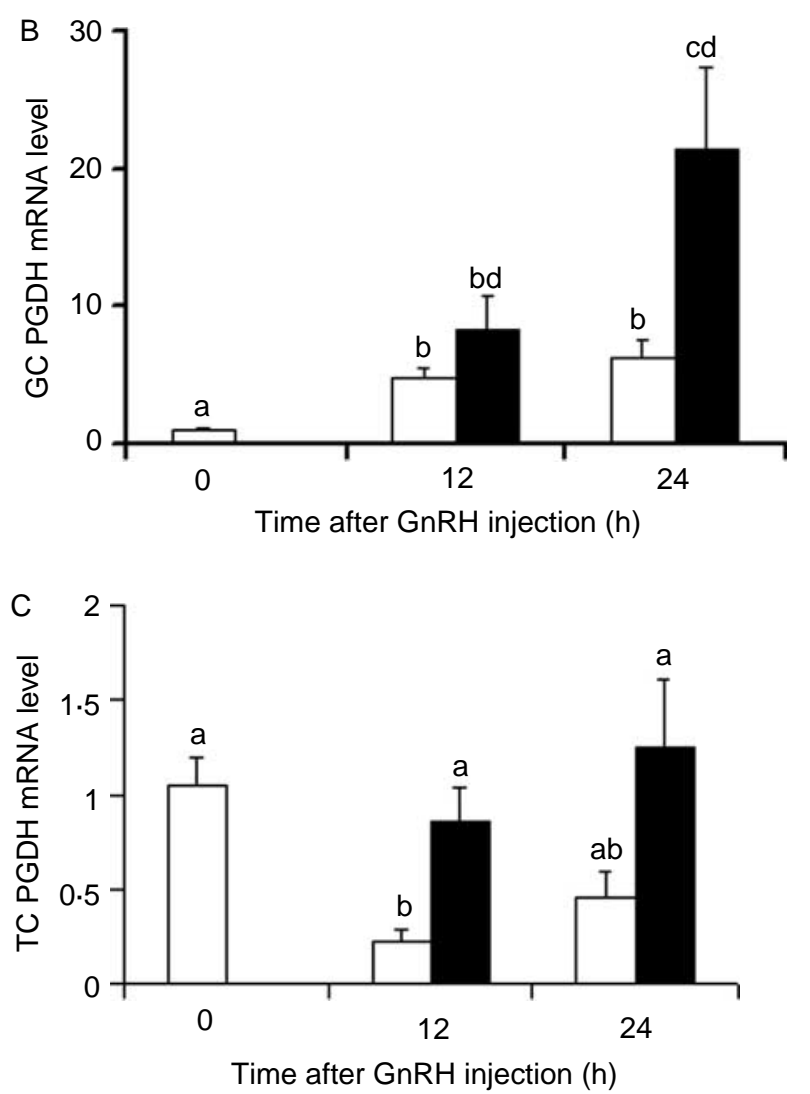

Figure 4 Quantitative real-time PCR analysis of the effect of trilostane (TRI) injection on cyclooxygenase-2 (COX-2) and prostaglandin dehydrogenase (PGDH) mRNA abundance in granulosal cells $(\mathrm{GC})$ and thecal tissue (TC) of bovine preovulatory follicles. Abundance of GC COX-2 mRNA (A) and PGDH mRNA in GC (B) and TC (C) was normalized relative to that of RPL-19 mRNA. Relative mRNA abundance at $12 \mathrm{~h}(n=3$ and 5 for CON and TRI respectively) and $24 \mathrm{~h}$ ( $n=5$ and 6 for CON and TRI respectively) was calculated using $\Delta \Delta \mathrm{CT}$ method. Due to undetectable COX-2 mRNA at 0-h timepoint, COX-2 mRNA abundance at the 12-h timepoints was used as calibrator. Data are shown as means \pm S.E.M. Bars without a common letter are different at $P<0 \cdot 05$.
$(P<0 \cdot 05$; Fig. 4C). In response to intrafollicular trilostane injection, PGDH mRNA abundance was increased (compared with controls) in GC and TC at 24 and $12 \mathrm{~h}$ respectively, following $\mathrm{GnRH}$ injection $(P<0 \cdot 05$; Fig. 4B and $\mathrm{C}$ ).

Effect of intrafollicular administration of trilostane on MMP and TIMP expression in preovulatory follicles

Since intrafollicular trilostane administration suppressed intrafollicular progesterone and $\mathrm{PGE}_{2}$ concentrations, effects of trilostane administration on protein/activity and (or) mRNA for MMPs and TIMPs associated with bovine follicle rupture were determined. Among the seven MMPs and TIMPs examined (MMP-13, MMP-14, MMP-28, and TIMPs 1-4), only abundance of TIMP-4 mRNA was affected by trilostane injection (data not shown for MMP13, MMP-14, MMP-28, and TIMPs 1-3). Trilostane treatment blocked the transient gonadotropin surge-induced increase in GC and TC TIMP-4 mRNA observed $12 \mathrm{~h}$ after GnRH injection $(P<0 \cdot 05$; Fig. 5A and B). TIMP-4 protein was detected as a single band of $28000 M_{\mathrm{r}}$ in bovine follicle homogenates, but no significant differences were detected in the amount of TIMP-4 protein in trilostane-treated versus control follicles in both the apex and the base (Fig. 5C and D).

Effect of intrafollicular administration of trilostane on GC and $T C$ plasminogen activator system component $m R N A$ abundance and activity

Gonadotropin surge-induced regulation of mRNA abundance for tPA and uPAR was not influenced by intrafollicular trilostane administration (data not shown). At $12 \mathrm{~h}$ after GnRH injection, uPA mRNA abundance in both GC and TC $(P<0 \cdot 05$; Fig. 6A and $\mathrm{B})$ was transiently increased in trilostane-treated versus control follicles. Relative to controls, trilostane treatment blocked the gonadotropin surge-induced increase in GC PAI-1 and PAI-2 mRNAs in follicles collected 24-h post-GnRH injection $(P<0 \cdot 05$; Fig. $6 \mathrm{C}$ and $\mathrm{D})$. In contrast to the observed effects of trilostane administration on uPA, PAI-1, and PAI-2 mRNAs, no effects of intrafollicular trilostane administration on tPA, uPA, and plasmin activities in the follicular apex, base, or follicular fluid were observed (Fig. 7).

\section{Discussion}

A role for increased intrafollicular progesterone in ovulation has been established in several species, including rat (Snyder et al. 1984, Brannstrom \& Janson 1989, Espey et al. 1990), sheep (Murdoch et al. 1986), and monkey (Hibbert et al. 1996, Chaffin \& Stouffer 2002). Furthermore, a requirement of the progesterone receptor for ovulation in mice has been demonstrated using gene targeting technology (Lydon et al. 1995, 1996). Although data in the mouse support a potential 

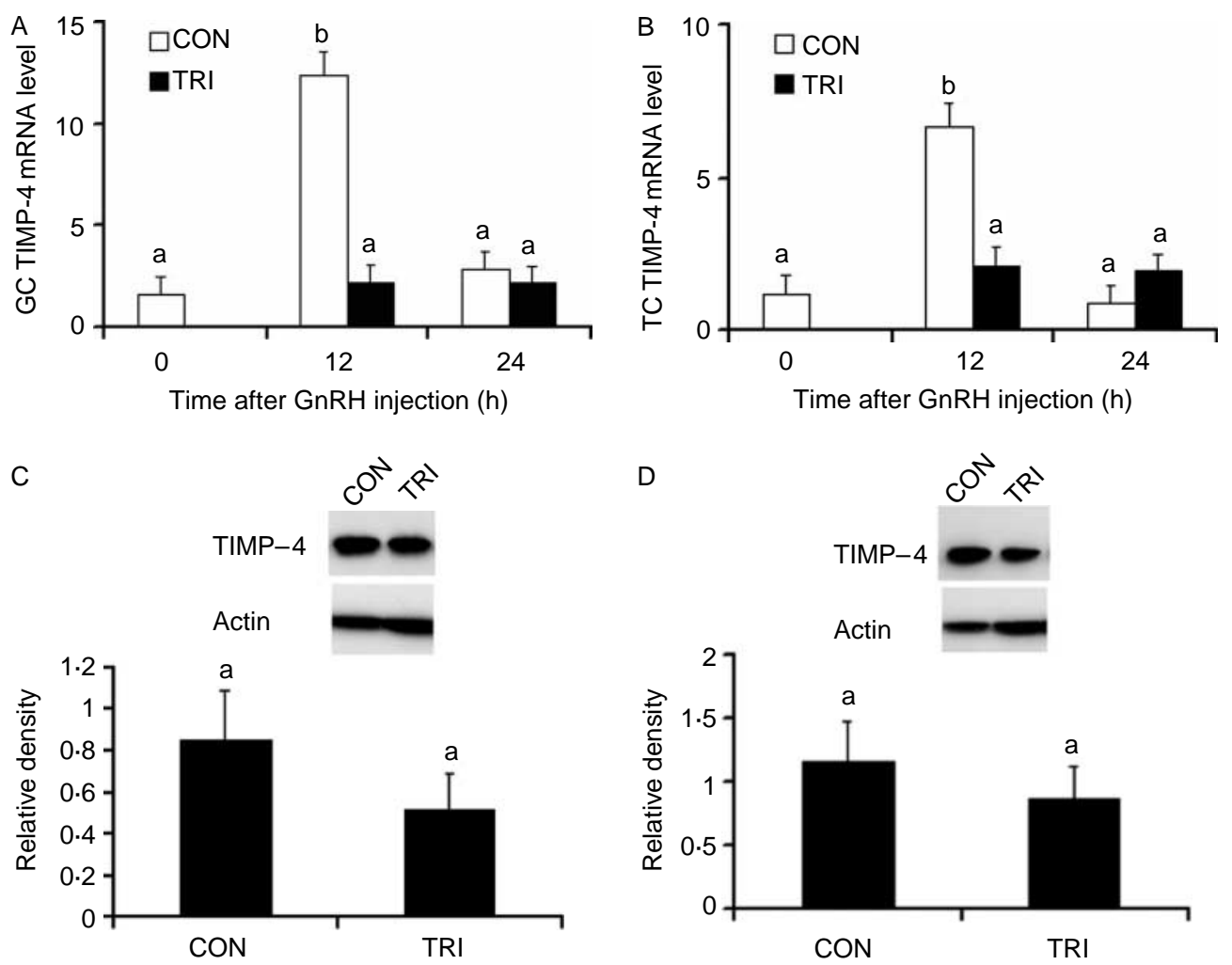

Figure 5 Changes in tissue inhibitor of metalloproteinases-4 (TIMP-4) mRNA abundance in granulosa cells (GC) and thecal tissue (TC) and TIMP-4 protein in the apex and base of bovine preovulatory follicles following intrafollicular trilostane (TRI) injection. Abundance of TIMP-4 mRNA in GC (A) and TC (B) was normalized relative to that of RPL-19 mRNA. Relative mRNA abundance at $12 \mathrm{~h}(n=3$ and 5 for CON and TRI respectively) and $24 \mathrm{~h}$ ( $n=5$ and 6 for CON and TRI respectively) was calculated using $\Delta \Delta C T$ method. Amounts of TIMP-4 protein in follicle apex (C) and base (D) were normalized relative to amounts of actin and quantified by densitometry. Bars without a common letter are different at $P<0 \cdot 05$.

role for progesterone-mediated regulation of a disintegrin and metalloproteinase with thrombospondin motifs (ADAMTS-1) (Robker et al. 2000, Mittaz et al. 2004) and cathepsin $\mathrm{L}$ proteinases in the ovulatory process (Robker et al. 2000), the intrafollicular targets of progesterone action that mediate the follicular extracellular matrix remodeling leading to follicle rupture are not completely understood. Using the bovine model system and ultrasound-mediated intrafollicular injection procedures, we determined the effect of inhibition of the preovulatory increase in intrafollicular progesterone (through intrafollicular trilostane injection) on follicle rupture, luteinization/luteal development, and expression of select regulators of follicular extracellular matrix remodeling, and prostaglandin biosynthesis and metabolism in bovine preovulatory follicles. Surprisingly, results of the present studies suggest that the preovulatory increase in intrafollicular progesterone per se is not obligatory for ovulation or gonadotropin surge-induced regulation of mRNA and activity/protein for the majority of the matrix-degrading proteinases and their inhibitors previously linked to the ovulatory process in cattle. Results, however, do suggest that increased follicular fluid progesterone may play a role in preovulatory regulation of intrafollicular $\mathrm{PGE}_{2}$ and $\mathrm{PGF}_{2 \alpha}$ concentrations and mRNA for the PGDH enzyme involved in prostanoid metabolism (Tai et al. 2002).

There is significant evidence supporting progesterone responsiveness of GC from bovine preovulatory follicles. Progesterone receptor mRNA is transiently upregulated in bovine follicles within $6 \mathrm{~h}$ following GnRH injection to induce the preovulatory gonadotropin surge (Cassar et al. 2002, Jo et al. 2002) and was localized primarily to the GC layer of preovulatory follicles (Cassar et al. 2002). Oxytocin mRNA is induced in the GC layer of bovine follicles following the $\mathrm{LH}$ surge and is correlated with hormonal events of the preovulatory period associated with luteinization (Voss \& Fortune 1992). Induction of oxytocin mRNA expression by luteinized bovine GC can be blocked by progesterone receptor antagonists in vitro (Lioutas et al. 1997, Jo et al. 2002). Given widespread reports of a role for progesterone/progesterone receptor in the ovulatory process in multiple species (Snyder et al. 1984, Murdoch et al. 1986, Brannstrom \& Janson 1989, Espey et al. 1990, 

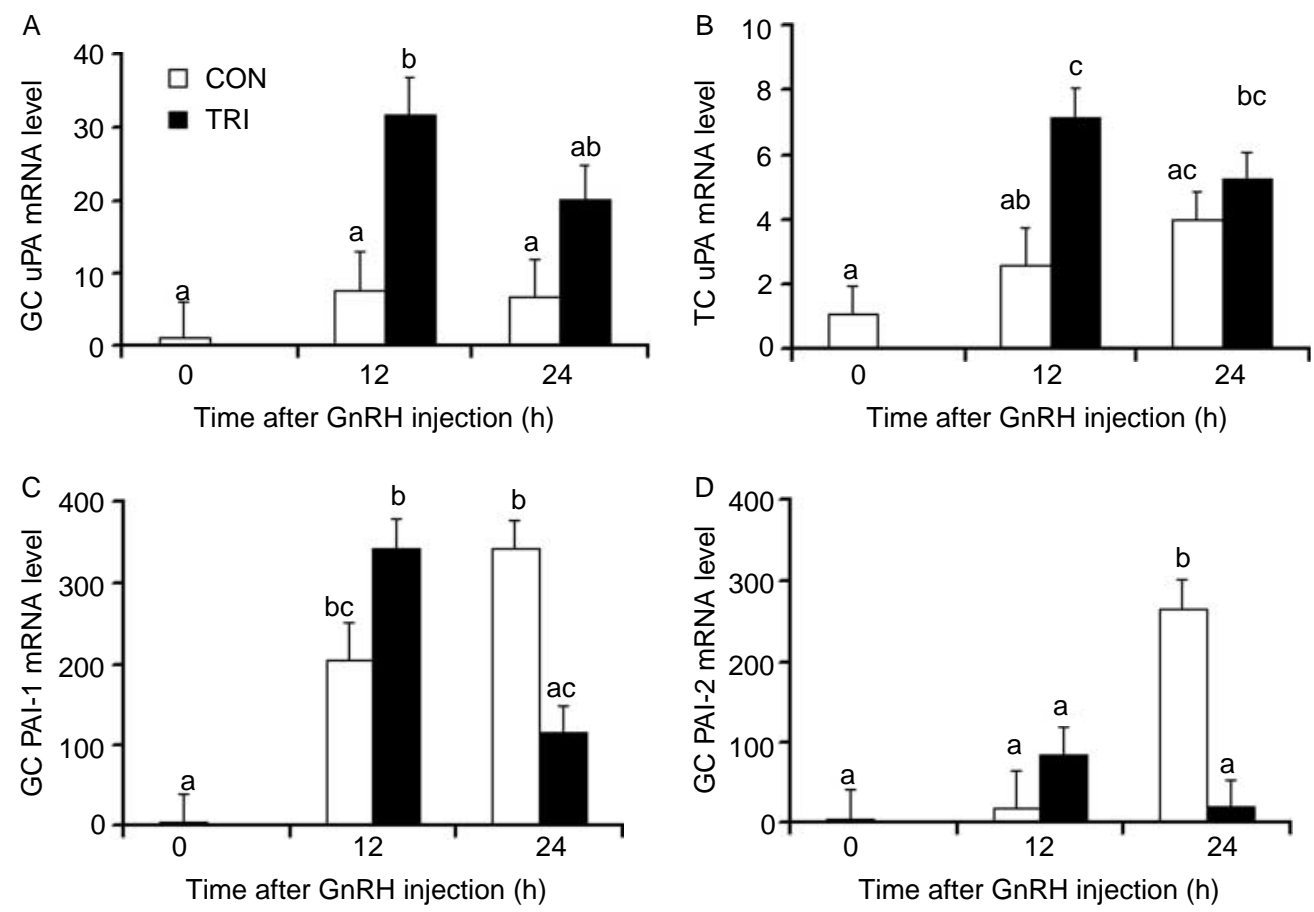

Figure 6 Quantitative real-time PCR analysis of the effect of trilostane (TRI) injection on urokinase plasminogen activator (UPA) and plasminogen activator inhibitors 1 and 2 (PAI-1 and PAI-2) mRNA abundance in granulosal cells (GC) and thecal tissue (TC) of bovine preovulatory follicles. Abundance of uPA (A and B), PAI-1 (C), and PAI-2 (D) mRNA was normalized relative to that of RPL-19 mRNA. Relative mRNA abundance at $12 \mathrm{~h}$ ( $n=3$ and 5 for CON and TRI respectively) and $24 \mathrm{~h}(n=5$ and 6 for CON and TRI respectively) was calculated using $\Delta \Delta C T$ method. Data are shown as the LS mean \pm pooled S.E.M. Bars without a common letter are different at $P<0 \cdot 05$.

Lydon et al. 1995, 1996, Hibbert et al. 1996, Chaffin \& Stouffer 2002), it is unlikely that progesterone plays no role in the ovulatory process in cattle. Instead, it seems plausible that while significantly reduced below control levels, concentrations of progesterone present in trilostane-treated bovine follicles were still sufficient to transactivate the progesterone receptor and stimulate expression of progesterone responsive genes. Concentrations of progesterone detected in follicular fluid of trilostane-treated follicles are orders of magnitude greater than progesterone concentrations in serum during the luteal phase, which are sufficient to stimulate progesterone-responsive genes in target tissues. The observed lack of an effect of trilostane administration on GC oxytocin mRNA abundance in the present studies would support this conclusion, given the above-described negative effect of progesterone receptor antagonists on GC oxytocin mRNA (Lioutas et al. 1997, Jo et al. 2002). Moreover, it has been shown that the LH surge induces both an early and a late increase in progesterone in bovine follicular fluid (Dieleman et al. 1983). Although trilostane blocked/delayed the presumed second rise in intrafollicular progesterone, we cannot conclude that the potential first rise in intrafollicular progesterone was efficiently blocked in the present study. Furthermore, we cannot discount potential unknown confounding effects of trilostane administration in animals induced to ovulate in response to an $\mathrm{LH}$ surge triggered by exogenous $\mathrm{GnRH}$ administration (in the present study) versus an endogenous LH surge. Nevertheless, results strongly indicate that the preovulatory increase in intrafollicular progesterone may not be required for ovulation in cattle.

Results in primates indicate that periovulatory progesterone production is required for normal corpus luteum function. Mid-cycle oral administration of trilostane to rhesus monkeys (days $0-2$ relative to ovulation induction with human chorionic gonadotropin (hCG)) blocks ovulation and reduces serum progesterone concentrations through day 6 following hCG administration (Hibbert et al. 1996). However, progesterone receptor antagonist treatment of cultured bovine luteal cells does not support a role for progesterone in regulation of its own biosynthesis in cattle (Rueda et al. 2000). In the present studies, no effect of intrafollicular trilostane administration on GC oxytocin mRNA abundance and serum progesterone concentrations through approximately day 9 of the subsequent luteal phase was noted, indicating that increased intrafollicular progesterone is likely not required for normal luteinization/luteal development in cattle. 

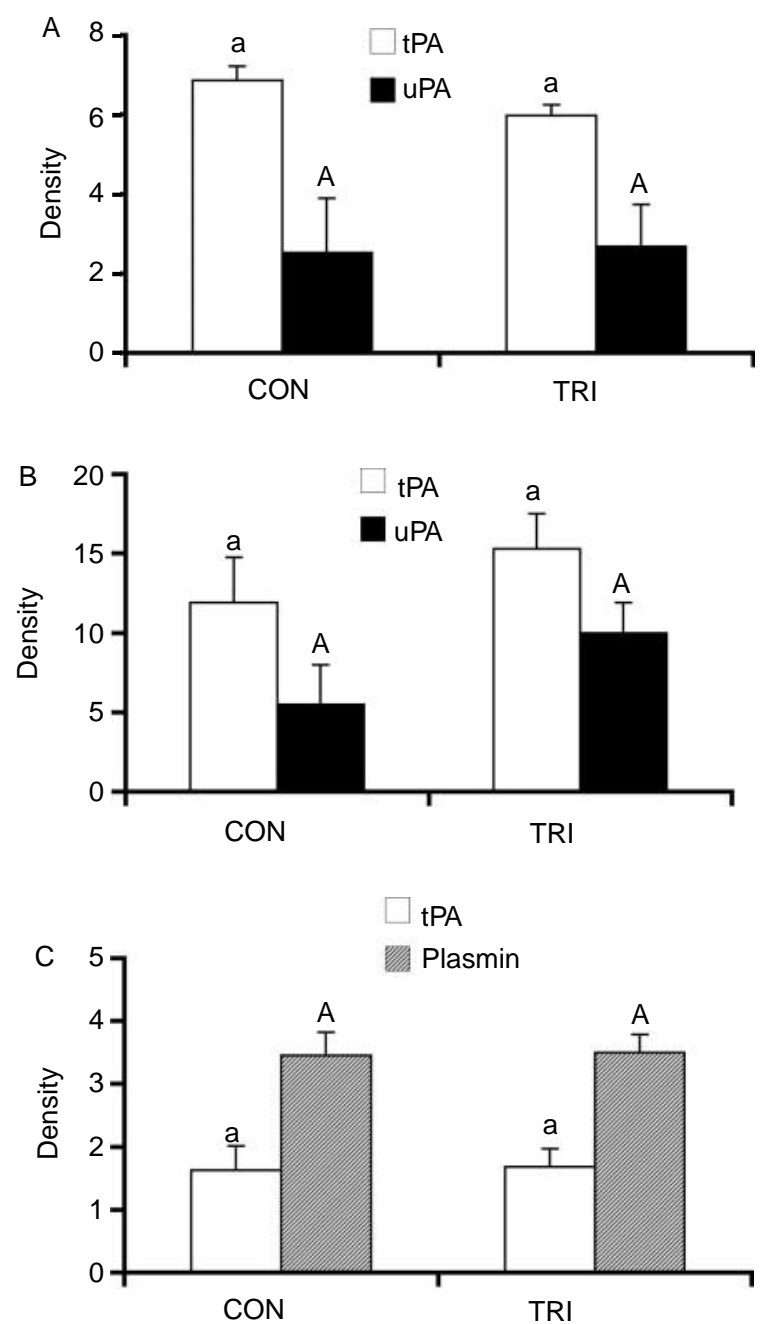

Figure 7 Zymographic analysis of the effect of intrafollicular trilostane injection on tPA, UPA, and plasmin activity in follicle apex, base, and follicular fluid of bovine preovulatory follicles collected at 12-h post-GnRH injection. Effects of TRI injection on the activity of tPA, uPA, and/or plasmin in follicle apex (A), base (B), and follicular fluid (C) were analyzed by densitometry $(n=3$ and 5 for CON and TRI respectively). Data are shown as LS mean \pm S.E.M. Bars without a common letter (A and B: lower case for PPA and upper case for UPA; C: lower case for $\mathrm{PAA}$ and upper case for plasmin) are different at $P<0 \cdot 05$. CON, diluent-treated follicles; TRI, trilostane-treated follicles.

Prostanoids play an obligatory role in the ovulatory process in numerous species (Murdoch et al. 1986, Dinchuk et al. 1995, Lim et al. 1997, Mikuni et al. 1998) including cattle (De Silva \& Reeves 1985, Peters et al. 2004). A reduction in follicular fluid $\mathrm{PGE}_{2}$ and $\mathrm{PGF}_{2 \alpha}$ concentrations was observed in trilostane-treated follicles in the present studies, suggestive of a role for progesterone in the regulation of preovulatory prostanoid levels. Intrafollicular administration of the progesterone synthesis inhibitor isoxazol in sheep results in the maintenance of elevated $\mathrm{PGE}_{2}$ concentrations, but a reduction in $\mathrm{PGF}_{2 \alpha}$ concentrations in the follicle wall within the last 4 to 8 -h of anticipated time of follicle rupture (Murdoch et al. 1986). However, in contrast to results of the present studies, isoxazol treatment of bovine follicles caused a pronounced inhibition of ovulation (Murdoch et al. 1986). Our results in cattle support a potential role for increased intrafollicular progesterone in promoting maintenance of elevated intrafollicular $\mathrm{PGE}_{2}$ and $\mathrm{PGF}_{2 \alpha}$ concentrations prior to ovulation.

Observed reductions in follicular fluid $\mathrm{PGE}_{2}$ and $\mathrm{PGF}_{2 \alpha}$ concentrations in response to intrafollicular trilostane injection may be due to modulation of mRNA abundance for genes regulating prostaglandin biosynthesis and (or) metabolism. Abundance of mRNA for COX-1 and COX2 was not affected by intrafollicular trilostane administration. Unlike the effect of trilostane, the progesterone receptor antagonist mifepristone inhibited LH-induced expression of cyclooxygenase- 2 mRNA and $\mathrm{PGE}_{2}$ and $\mathrm{PGF}_{2 \alpha}$ secretion by granulosal cells (Bridges et al. 2006). However, intrafollicular trilostane administration increased TC mRNA abundance for PGDH at the 12-h timepoint to levels similar to those observed at time 0 and caused a further increase in GC PGDH mRNA abundance at the 24-h timepoint. Hormonal and cell-specific regulation of $\mathrm{PGDH}$ has been examined previously in a primate model, with results distinct from those observed in the present studies. A transient increase in PGDH mRNA was observed in monkey granulosal cells collected $12 \mathrm{~h}$ after hCG administration and PGDH protein was localized exclusively to the granulosal layer (Duffy et al. 2005). In vitro progesterone treatment of cultured monkey granulosal cells for $24 \mathrm{~h}$ did not change PGDH mRNA levels, but 48-h exposure resulted in reduced $\mathrm{PGDH}$ mRNA abundance (Duffy et al. 2005). Collectively, results of the present studies suggest that increased expression of PGDH, but not COX-1 and COX-2 mRNAs, in GC and TC could contribute to the observed reduction in intrafollicular $\mathrm{PGE}_{2}$ and $\mathrm{PGF}_{2 \alpha}$ in trilostane-treated follicles.

It is unclear why the observed decrease in intrafollicular prostaglandins in trilostane-treated follicles was not sufficient to block ovulation in the present studies. In the present study, follicular fluid $\mathrm{PGE}_{2}$ concentrations at 24-h post-GnRH injection were $>20$-fold higher in trilostane-treated follicles than observed in indomethacin-treated follicles (at the same timepoint) in a previous study where dynamic changes in protein abundance/activity and (or) mRNA for multiple MMP and PA system components were observed (Li et al. 2006). Although more variable, the concentrations of $\mathrm{PGE}_{2}$ in follicles treated with the selective COX-2 inhibitor NS398 (where a reduction in ovulation rate was noted) were similar (De Silva \& Reeves 1985, Peters et al. 2004) to those observed following intrafollicular trilostane administration in the present studies. It is possible that the precise timing of the reduction in intrafollicular $\mathrm{PGE}_{2}$, potentially mediated through the regulation of $\mathrm{PGDH}$ metabolism, may have been insufficient to inhibit ovulation in the present studies. Consistent with this hypothesis, the effects of intrafollicular 
trilostane administration did not mimic changes in protein abundance/activity and (or) mRNA for MMP and PA system components observed in previous studies where intrafollicular synthesis of prostanoids was inhibited by intrafollicular indomethacin administration (Li et al. 2006) and discordant effects of trilostane on mRNA versus protein/activity were observed in some instances (e.g. TIMP-4).

While inhibition of the preovulatory increase in intrafollicular progesterone did not block follicle rupture, subsequent luteal development or gonadotropin surgeinduced regulation of mRNA and (or) protein/activity for the majority of the matrix-degrading proteinases and their inhibitors potentially linked to the ovulatory process in cattle, paradoxical effects of intrafollicular trilostane administration on follicular fluid $\mathrm{PGE}_{2}$ and $\mathrm{PGF}_{2 \alpha}$ concentrations, and abundance of mRNA for PGDH, TIMP-4, uPA, PAI1, and PAI-2 were observed. The mechanisms responsible for the above-observed effects of trilostane administration, and lack of an effect of trilostane administration on established progesterone receptor-mediated pathways in bovine follicles (e.g. oxytocin expression) are unclear. While observed responses are most likely attributed to the inhibition of the intrafollicular increase in progesterone, trilostane administration also enhanced the rate of the preovulatory decrease in follicular fluid estradiol concentrations, presumably by an enhanced reduction in the availability of TC precursors for GC estradiol biosynthesis. It is unlikely that the observed effects of trilostane administration are due to accelerated depletion of intrafollicular estradiol. Follicular fluid estradiol concentrations in trilostane-treated bovine follicles were still over 1000fold greater than circulating estradiol concentrations measured at similar timepoints (Sartori et al. 2004), which are known to trigger the preovulatory $\mathrm{GnRH} / \mathrm{LH}$ surge. Observed effects of blocking the preovulatory increase in intrafollicular progesterone could also be due to inhibition of nonclassical progesterone-mediated responses requiring high concentrations of progesterone that are independent of the classical progesterone receptor. Microgram quantities of progesterone can induce expression of steroidogenic acute regulatory protein $\mathrm{mRNA}$ and protein in MA-10 Leydig tumor cells, which lack the classical form of the progesterone receptor (Schwarzenbach et al. 2003).

In summary, results of the present studies indicate that the preovulatory increase in intrafollicular progesterone may not be required for follicle rupture, subsequent luteal development, or gonadotropin surge-induced regulation of the majority of the matrix-degrading proteinases, and their inhibitors previously linked to the ovulatory process in cattle. Future studies will be required to determine the mechanisms responsible for observed paradoxical effects of inhibition of the preovulatory increase in progesterone and to determine the effects of in vivo antagonism of intrafollicular progesterone receptor-mediated pathways on follicle rupture, luteinization, and regulation of intrafollicular mediators linked to the ovulatory process in cattle.

\section{Acknowledgements}

The authors wish to thank Dr Osman Patel, Larry Chapin, Heather Dover, Dr Monika Mihm, Nora Bello, Crystal Huston, Tracey Pierzchala, and Katie Pierson for excellent assistance with animal handling and tissue collection and are grateful to Larry Chapin for assistance with the statistical analysis. The authors also wish to graciously thank SanofiSynthelabo Research for providing the trilostane used in the current studies.

\section{Funding}

This project was supported by National Research Initiative Competitive Grant no. 2003-35203-12841 from the USDA Cooperative State Research, Education, and Extension Service to G W S. The authors declare that there is no conflict of interest that would prejudice impartiality of this scientific work.

\section{References}

Bakke LJ, Dow MP, Cassar CA, Peters MW, Pursley JR \& Smith GW 2002 Effect of the preovulatory gonadotropin surge on matrix metalloproteinase (MMP)-14, MMP-2, and tissue inhibitor of metalloproteinases-2 expression within bovine periovulatory follicular and luteal tissue. Biology of Reproduction 66 1627-1634.

Bakke LJ, Li Q, Cassar CA, Dow MP, Pursley JR \& Smith GW 2004 Gonadotropin surge-induced differential upregulation of interstitial collagenase (MMP-1) and collagenase-3 (MMP-13) mRNA and protein in bovine preovulatory follicles. Biology of Reproduction 71 605-612.

Brannstrom M \& Janson PO 1989 Progesterone is a mediator in the ovulatory process of the in vitro-perfused rat ovary. Biology of Reproduction 401170 1178.

Bridges PJ, Komar CM \& Fortune JE 2006 Gonadotropin-induced expression of messenger ribonucleic acid for cyclooxygenase-2 and production of prostaglandins $\mathrm{E}$ and $\mathrm{F} 2$ alpha in bovine preovulatory follicles are regulated by the progesterone receptor. Endocrinology 147 4713-4722.

Cassar CA, Dow MP, Pursley JR \& Smith GW 2002 Effect of the preovulatory LH surge on bovine follicular progesterone receptor mRNA expression. Domestic Animal Endocrinology 22 179-187.

Chaffin CL \& Stouffer RL 1999 Expression of matrix metalloproteinases and their tissue inhibitor messenger ribonucleic acids in macaque periovulatory granulosa cells: time course and steroid regulation. Biology of Reproduction 61 14-21.

Chaffin CL \& Stouffer RL 2002 Local role of progesterone in the ovary during the periovulatory interval. Reviews in Endocrine and Metabolic Disorders 3 65-72.

De Silva M \& Reeves JJ 1985 Indomethacin inhibition of ovulation in the cow. Journal of Reproduction and Fertility 75 547-549.

Dieleman SJ, Kruip TA, Fontijne P, de Jong WH \& van der Weyden GC 1983 Changes in oestradiol, progesterone and testosterone concentrations in follicular fluid and in the micromorphology of preovulatory bovine follicles relative to the peak of luteinizing hormone. Journal of Endocrinology 97 31-42.

Dinchuk JE, Car BD, Focht RJ, Johnston JJ, Jaffee BD, Covington MB, Contel NR, Eng VM, Collins RJ, Czerniak PM et al. 1995 Renal abnormalities and an altered inflammatory response in mice lacking cyclooxygenase II. Nature 378 406-409.

Dow MP, Bakke LJ, Cassar CA, Peters MW, Pursley JR \& Smith GW 2002a Gonadotropin surge-induced up-regulation of the plasminogen activators 
(tissue plasminogen activator and urokinase plasminogen activator) and the urokinase plasminogen activator receptor within bovine periovulatory follicular and luteal tissue. Biology of Reproduction 66 1413-1421.

Dow MP, Bakke LJ, Cassar CA, Peters MW, Pursley JR \& Smith GW $2002 b$ Gonadotrophin surge-induced upregulation of mRNA for plasminogen activator inhibitors 1 and 2 within bovine periovulatory follicular and luteal tissue. Reproduction 123 711-719.

Duffy DM, Dozier BL \& Seachord CL 2005 Prostaglandin dehydrogenase and prostaglandin levels in periovulatory follicles: implications for control of primate ovulation by prostaglandin E2. Journal of Clinical Endocrinology and Metabolism 90 1021-1027.

Espey LL, Adams RF, Tanaka N \& Okamura H 1990 Effects of epostane on ovarian levels of progesterone, 17 beta-estradiol, prostaglandin E2, and prostaglandin F2 alpha during ovulation in the gonadotropin-primed immature rat. Endocrinology 127 259-263.

Fata JE, Ho AT, Leco KJ, Moorehead RA \& Khokha R 2000 Cellular turnover and extracellular matrix remodeling in female reproductive tissues: functions of metalloproteinases and their inhibitors. Cellular and Molecular Life Sciences $\mathbf{5 7}$ 77-95.

Hibbert ML, Stouffer RL, Wolf DP \& Zelinski Wooten MB 1996 Midcycle administration of a progesterone synthesis inhibitor prevents ovulation in primates. PNAS 93 1897-1901.

Iwamasa J, Shibata S, Tanaka N, Matsuura K \& Okamura H 1992 The relationship between ovarian progesterone and proteolytic enzyme activity during ovulation in the gonadotropin-treated immature rat. Biology of Reproduction 46 309-313.

Jimenez Krassel F \& Ireland JJ 2002 Development and validation of a shortterm, serum-free culture system for bovine granulosa cells: evaluation of the effects of somatotropin and growth hormone-releasing factor on estradiol production. Journal of Dairy Science 85 68-78.

Jo M, Komar CM \& Fortune JE 2002 Gonadotropin surge induces two separate increases in messenger RNA for progesterone receptor in bovine preovulatory follicles. Biology of Reproduction 67 1981-1988.

Li Q, Bakke LJ, Pursley JR \& Smith GW 2004 Localization and temporal regulation of tissue inhibitors of metalloproteinases 3 and 4 in bovine preovulatory follicles. Reproduction 128 555-564.

Li Q, Jimenez-Krassel F, Kobayashi Y, Ireland JJ \& Smith GW 2006 Effect of intrafollicular indomethacin injection on gonadotropin surge-induced expression of select extracellular matrix degrading enzymes and their inhibitors in bovine preovulatory follicles. Reproduction 131 533-543.

Lim H, Paria BC, Das SK, Dinchuk JE, Langenbach R, Trzaskos JM \& Dey SK 1997 Multiple female reproductive failures in cyclooxygenase 2-deficient mice. Cell 91 197-208.

Lioutas C, Einspanier A, Kascheike B, Walther N \& Ivell R 1997 An autocrine progesterone positive feedback loop mediates oxytocin upregulation in bovine granulosa cells during luteinization. Endocrinology 138 5059-5062.

Livak KJ \& Schmittgen TD 2001 Analysis of relative gene expression data using real-time quantitative PCR and the $2(-$ Delta Delta $C(T))$ method. Methods 25 402-408.

Lowry OH, Rosebrough NJ, Farr AL \& Randall RJ 1951 Protein measurement with the Folin phenol reagent. Journal of Biological Chemistry 193 265-275.

Lydon JP, DeMayo FJ, Funk CR, Mani SK, Hughes AR, Montgomery CA, Shyamala G, Conneely OM \& O'Malley BW 1995 Mice lacking progesterone receptor exhibit pleiotropic reproductive abnormalities. Genes and Development 9 2266-2278.

Lydon JP, DeMayo FJ, Conneely OM \& BW OM 1996 Reproductive phenotpes of the progesterone receptor null mutant mouse. Journal of Steroid Biochemistry and Molecular Biology 56 67-77.

Mikuni M, Pall M, Peterson CM, Peterson CA, Hellberg P, Brannstrom M, Richards JS \& Hedin L 1998 The selective prostaglandin endoperoxide synthase-2 inhibitor, NS-398, reduces prostaglandin production and ovulation in vivo and in vitro in the rat. Biology of Reproduction 59 1077-1083.
Mittaz L, Russell DL, Wilson T, Brasted M, Tkalcevic J, Salamonsen LA, Hertzog PJ \& Pritchard MA 2004 Adamts-1 is essential for the development and function of the urogenital system. Biology of Reproduction 70 1096-1105.

Murdoch WJ, Peterson TA, Van Kirk EA, Vincent DL \& Inskeep EK 1986 Interactive roles of progesterone, prostaglandins, and collagenase in the ovulatory mechanism of the ewe. Biology of Reproduction 35 1187-1194.

Ny T, Wahlberg P \& Brandstrom IJ 2002 Matrix remodeling in the ovary: regulation and functional role of the plasminogen activator and matrix metalloproteinase systems. Molecular and Cellular Endocrinology 187 29-38.

Peters MW, Pursley JR \& Smith GW 2004 Inhibition of intrafollicular PGE2 synthesis and ovulation following ultrasound-mediated intrafollicular injection of the selective cyclooxygenase-2 inhibitor NS-398 in cattle. Journal of Animal Science 82 1656-1662.

Pursley JR, Mee MO \& Wiltbank MC 1995 Synchronization of ovulation in dairy cows using PGF2alpha and GnRH. Theriogenology 44 915-923.

Pursley JR, Kosorok MR \& Wiltbank MC 1997 Reproductive management of lactating dairy cows using synchronization of ovulation. Journal of Dairy Science 80 301-306.

Robker RL, Russell DL, Espey LL, Lydon JP, O'Malley BW \& Richards JS 2000 Progesterone-regulated genes in the ovulation process: ADAMTS-1 and cathepsin L proteases. PNAS 97 4689-4694.

Rueda BR, Hendry IR, Hendry IW, Stormshak F, Slayden OD \& Davis JS 2000 Decreased progesterone levels and progesterone receptor antagonists promote apoptotic cell death in bovine luteal cells. Biology of Reproduction 62 269-276.

Sartori R, Haughian JM, Shaver RD, Rosa GJ \& Wiltbank MC 2004 Comparison of ovarian function and circulating steroids in estrous cycles of Holstein heifers and lactating cows. Journal of Dairy Science 87 905-920.

Schwarzenbach H, Manna PR, Stocco DM, Chakrabarti G \& Mukhopadhyay AK 2003 Stimulatory effect of progesterone on the expression of steroidogenic acute regulatory protein in MA-10 Leydig cells. Biology of Reproduction 68 1054-1063.

Sirois J 1994 Induction of prostaglandin endoperoxide synthase-2 by human chorionic gonadotropin in bovine preovulatory follicles in vivo. Endocrinology 135 841-848.

Smith GW, Juengel JL, McLntush EW, Youngquist RS, Garverick HA \& Smith MF 1996 Ontogenies of messenger RNA encoding tissue inhibitor of metalloproteinases 1 and 2 within bovine periovulatory follicles and luteal tissue. Domestic Animal Endocrinology 13 151-160.

Snyder BW, Beecham GD \& Schane HP 1984 Inhibition of ovulation in rats with epostane, an inhibitor of 3 beta-hydroxysteroid dehydrogenase. Proceedings of the Society for Experimental Biology and Medicine 176 238-242.

Tai HH, Ensor CM, Tong M, Zhou H \& Yan F 2002 Prostaglandin catabolizing enzymes. Prostaglandins and Other Lipid Mediators 68-69 483-493.

Tanaka N, Espey LL, Stacy S \& Okamura H 1992 Epostane and indomethacin actions on ovarian kallikrein and plasminogen activator activities during ovulation in the gonadotropin-primed immature rat. Biology of Reproduction 46 665-670.

Voss AK \& Fortune JE 1992 Oxytocin/neurophysin-I messenger ribonucleic acid in bovine granulosa cells increases after the luteinizing hormone (LH) surge and is stimulated by LH in vitro. Endocrinology 131 2755-2762.

Received in final form 11 December 2006 Accepted 13 December 2006 Made available online as an Accepted Preprint 28 December 2006 